\title{
ESTUDIO DE INOCULANTES PARA EL ENSILADO DE FORRAJES I: SELECCIÓN DE BACTERIAS PRODUCTORAS DEÁCIDO LÁCTICO PARA LA FORMULACIÓN DE UN INOCULANTE
}

\author{
Vicente, F. ${ }^{1}$, Scollo, D. ${ }^{1}$, Mora, V. ${ }^{1}$, \\ GIRAUDO, M. ${ }^{1}$, RAMIREZ, E. ${ }^{2}$ \& RECHIMONT, R. ${ }^{2}$
}

\begin{abstract}
RESUMEN
Fueron seleccionados varios microorganismos (cinco) productores de ácido láctico, extraídos de pasturas y cepas del cepario del Laboratorio de la UNLa, en función de la resistencia a la acidez o al poder simbiótico que genera la asociación. Estos microorganismos fueron probados en microsilos experimentales conteniendo una mezcla de gramíneas con un 10\% de trébol blanco. En los 5 casos se obtuvo una buena conservación de la pastura, y el mejor de ellos fue cuando los microorganismos se usaron mezclados en proporciones iguales.

Palabras claves: Ácido láctico, microorganismos, pasturas, silos, anaerobiosis, conservación, nutrición animal.
\end{abstract}

\section{SUMMARY}

\section{Study of inoculating for fodder silages I: selection of lactic acid produced} bacteria to be used in silaged fodders.

Several (five) lactic acid producer microorganisms were selected from forage silage samples taken at 7, 14 and 30 days from the beginning of the incubation considering their resistance to acidity or the symbiotic capacity produced by the association. These microorganisms were tested in experimental microsilos containing a mixture of ray-grass with $10 \%$ of white clover. A good preservation of the fodder was observed in the five cases, but the best result was obtained when the microorganisms were mixed in equal proportions.

Key words: lactic acid, microorganisms, fodder, silo, anaerobiosis, conservation, animal nutrition.

1.- Universidad Nacional de Lanús, 29 de Septiembre 3901. (1826) Lanús, provincia de Buenos Aires, tel.: (011) 6322-9200 int. 105, email: mgiraudo@unla.edu.ar 2.- NutriWorld Consultora.

Manuscrito recibido el 20 de marzo de 2008 y aceptado para su publicación el 21 de agosto de 2008 . 